\title{
Increased Potential of Protein Content of Waxy
}

\section{Corn}

\author{
Edy, Sudirman N., Baktiar I.
}

Faculty of Agriculture, University of Moslem Indonesia, Makassar, South Sulawesi, Indonesia

\begin{abstract}
The purpose of this research is to gain a potentially waxy corn strains of high protein content. Specific targets to be achieved in this study are promising lines of F1 that have potentially sticky and high protein content. The method used is cross-pollinated plant breeding methods, the hybridization between maize Variety of Srikandi Putih (q) and the Local Waxy Corn (ठ). Characters F1 compared to corn Variety of Srikandi Putih and the Local Waxy Corn. The results showed that character of plant height, number of leaves, and leaf area are higher in Srikandi Putih Variety compared to Local Waxy Corn but age flowering male and female Local Waxy Corn faster than Srikandi Putih Variety. Character length of ear, diameter of ear, weight of 100 seeds, seed weight plant $^{-1}$ and protein content higher in Srikandi Putih compared to Local Waxy Corn. F1 values on all observation characteristic of plant height, leaf number, leaf area, male and female flowering age, ear length, ear diameter, weight of 100 seeds, seed weight plant ${ }^{-1}$ and protein content were generally among the values of Srikandi Putih Variety and Local Waxy Corn.
\end{abstract}

Keywords - corn, sticky, protein, hybridization.

\section{INTRODUCTION}

Generally corn crops are used for animal feed, only a small portion is used for food and food industries. Along with the increasing number of population then the basic food needs must also be met. Therefore it is necessary to diversify the staple food, one of them by utilizing corn as an alternative staple food. To make corn as an alternative staple food needs to be improved quality and flavor to be tasty and nutritious. The merging of two good properties of two different corn varieties can be done if their genetic diversity is available. High quality protein maize (QPM) is available and already on the market, but the flavor is not delicious, making it less delicious for human consumption. The beginning of genetic improvement on protein quality was triggered by the discovery of opaque and floury genes which were reported to alter the lysine and tryptophan content of the seed endosperm [15].. Of the genes that have been identified, only opaque-2 (o2) and floury2 (fl2) genes are often used in improving the properties of corn endosperms [6], [8]. Similarly, local waxy corn is also available and can be obtained in the
South Sulawesi Region. This local waxy corn is one of South Sulawesi's typical corn with a taste that is very tasty and popular people, both young corn and processed old seeds because it contains high amylopectin, but the lack of production is low and protein content is less. Disadvantages of both types of corn need to be removed with certain plant breeding techniques to obtain high protein corn and feel sticky.

Corn with special properties can be established through repetitive plant breeding programs [2]. Amylopectin content in waxy corn nearly $100 \%$. Ordinary corn endosperms consist of a mixture of $72 \%$ amylopectin and $28 \%$ amylose [5]. According to Bates et al. (1943) in [1], the endosperm content of waxy corn is almost entirely amylopectin. In waxy corn there is a wx recessive gene in homozygous (wxwx) that affects the chemical composition of starch, causing tasty and savory taste. Backcross breeding methods can be applied to integrate the donor genes from specific corn of amylopectin-rich to high quality protein corn and high productivity. Thus, corn will be obtained which has the desired special properties.

\section{Research Purposes}

The purpose of this research is to obtain high potential protein content of waxy corn strain as a forerunner of high quality corn and delicious and nutritious flavor to be consumed as an alternative staple food that the price is affordable

\section{METHODS}

The research was conducted in the Village Antang, SubDistrict Manggala, Makassar, which took place in September 2016 until March 2017. Materials used in this study are: Seed corn of Variety of Srikandi Putih, seed corn of waxy corn, Urea, SP-36, $\mathrm{KCl}$, compost, pesticide, paper bags, labels, paper HVS, rope, plastic bags. The tools used are: hoes, shovels, scissors, tape measure, digital scales, electric oven, shove, hand sprayer and hype.

This study was designed using Cross-breeding methods in cross-pollinated plants, that is hybridization between Local waxy corn with Variety of Srikandi Putih. Model planting as follows: Variety of Srikandy Putih as female parents (P1) planted 3 rows while Locally waxy corn as 
the male parent (P2) planted one row. Each row consists of 15 plants. Repeated 5 times. The crosses between the Srikandi Putih variety and the local waxy corn will produce F1 generation.

\section{Implementation of Research}

Land to be planted conducted soil analysis to determine the level of soil fertility and pH. Further prepared seeds, compost, Urea, SP-36 and KCL and all the necessary equipment. Then the land is plowed and uniformly distributed and then made a plot of $2.5 \mathrm{~m} \times 3 \mathrm{~m}$ size of 5 plots, then given a compost of $20 \mathrm{~kg}$ per plot.. Srikandi Putih of corn seed and waxy corn previously given Ridomil fungicide to prevent disease. Because the age of flowering maize Variety of Srikandy Putih longer than local waxy corn, seed of Srikandi Putih is planted early 10 days and then waxy corn by way of as much as 2 seeds/hole with a spacing of $70 \mathrm{~cm}$ x $20 \mathrm{~cm}$. After that the seed of waxy corn is planted with the same way. Fertilizing Urea, SP-36 and $\mathrm{KCl}$ done after the corn crop was 7 days after planting (DAP) at a dose of $200 \mathrm{~kg}$ urea. $\mathrm{ha}^{-1}, 150 \mathrm{~kg}$ of SP-36.ha ${ }^{-1}$ and $100 \mathrm{~kg} \mathrm{KCl.ha}{ }^{-1}$. Urea special given 2 times, $50 \%$ at 7 DAP and $50 \%$ at the age of 50 DAP. After the plant was 7 DAP thinning to leave one plant. Weeding every two weeks.

\section{Plant Hybridization}

After both types of flowering corn crops, pollination is performed. Pollen mature waxy corn collected in paper bags then powdered into mature pistil head (silk) Srikandi Putih Variety. After that the pollinated female flowers (silk) are wrapped in paper bags that have been inscribed on date and the name of the genotype.

\section{Data Collection}

Data were observed: 1) Plant height; 2) leaf number; 3) Leaf area; 4). Age of male flowering ; 5) Age of female flowering; 6) Length of the ear; 7) Diameter of the ear; 8) The weight of 100 seeds. 9) The weight of seeds per plant; 10) The protein content

\section{Statistic analysis}

The data were analyzed descriptively of all the characters phenotype observed.

\section{RESULTS AND DISCUSSION}

\section{Plant Growth}

The average of observed growth of waxy corn and Srikandi Putih on various observation parameters is presented in Table 1.
Table 1. Average Waxy corn Growth and Srikandi Putih Growth Parameters

\begin{tabular}{|c|c|c|c|c|c|c|c|c|c|c|}
\hline No. & \multicolumn{2}{|c|}{$\begin{array}{c}\text { Plant height } \\
(\mathrm{cm})\end{array}$} & \multicolumn{2}{c|}{$\begin{array}{c}\text { Number of } \\
\text { leaves (sheet) }\end{array}$} & \multicolumn{2}{c|}{$\begin{array}{c}\text { Leaf area } \\
(\mathrm{cm})\end{array}$} & \multicolumn{2}{|c|}{$\begin{array}{c}\text { Age of } \\
\text { flowering } \\
\text { (day) }\end{array}$} & \multicolumn{2}{|c|}{$\begin{array}{c}\text { Age of } \\
\text { flowering } \\
\text { (day) }\end{array}$} \\
\cline { 2 - 11 } & WC & SP & WC & SP & WC & SP & WC & SP & WC & SP \\
\hline 1 & 144.5 & 159.8 & 8.0 & 10.0 & 395.5 & 421.3 & 47.0 & 56.0 & 49.0 & 58.0 \\
\hline 2 & 155.8 & 160.2 & 9.0 & 7.0 & 392.6 & 418.4 & 47.0 & 57.0 & 48.0 & 58.0 \\
\hline 3 & 158.2 & 162.5 & 7.0 & 8.0 & 378.9 & 412.8 & 46.0 & 55.0 & 48.0 & 56.0 \\
\hline 4 & 156.8 & 170.3 & 8.0 & 8.0 & 400.8 & 420.5 & 47.0 & 55.0 & 49.0 & 57.0 \\
\hline 5 & 156.4 & 168.2 & 9.0 & 9.0 & 388.8 & 416.7 & 46.0 & 57.0 & 47.0 & 59.0 \\
\hline Rataan & 154.3 & 164.2 & 8.2 & 8.4 & 391.3 & 417.9 & 46,6 & 56.0 & 48.2 & 57.6 \\
\hline
\end{tabular}

Note: $\mathrm{Wc}=$ Waxy corn, $\mathrm{SP}=$ Srikandi Putih

Table 1 shows Srikandi Putih Variety tend to provide higher growth ranging from plant height, leaf area, male flowering age and female flowering age are longer compared to Local Waxy Corn. Only the relatively equal number of leaves between the Srikandi Putih Variety and Local Waxy Corn. This is appropriate with the description of Srikandi Putih Variety. On the other side of Local Waxy Corn, the height of corn depends varieties, generally ranges from $100-300 \mathrm{~cm}$. The corn leaves extend and come out of the stem nodes. The number of leaves consists of 8-48 sheets depending on the variety [11]. Other studies have shown that the type of Srikandi Putih seed is generally pearl (flint corn), seeds like pearl, bloated and hard. White Waxy Corn is a variant of white corn. Status of white Waxy Corn by some farmers in South Sulawesi, NTB, NTT and Maluku is considered the same as white corn. Farmers grow white Waxy Corn to harvest young, eaten in the form of stew [10]. White Waxy Corn is white transparent, 85 days old and contains low amylose $(<10 \%)$ in seed endosperm.

\section{Production and Quality of Maize}

The average observed parameters of production and quality of corn are presented in Table 2. Table 2 shows Srikandi Putih Variety generally production tends to be higher compared to Waxy Corn and F1 generation. This can be seen in the production parameters ranging from length of ear, ear diameter, weight of 100 seeds and weight of seeds per plant. The results reported that Waxy Corn is a local maize that has low yield potential, ie less than $2 \mathrm{t} / \mathrm{ha}$, small cobs with a diameter of 10-11 mm and highly susceptible to disease [4]. Furthermore, reported that yield of Waxy Corn is about 35 percent lower than normal maize seed production and if planted it must be isolated from surrounding plants at least 200 meters [14]. Waxy corn is special type of corn is more and more needed, consumers and industries. Corn special marked its own advantages, such as amylopectin content high above 90 percent [9]. Similarly, in the parameter of protein content, where protein content in F1 generation is higher than Local Waxy Corn but still under Srikandi 
Putih. Interesting things can be observed between F1 with both parents (Lokal Waxy Corn and Srikandi Putih) which shows the value on each parameter of production and quality that tends to be between the value of both parents. This gives an indication that the properties of both parents have been inherited to $\mathrm{F} 1$, but the properties are still partial and not yet stable so still need further research to obtain new varieties. In line with the results of research that one of the efforts to increase the level of corn kernel protein is to utilize the xenia effect. The xenia effect itself can be interpreted as the pollen effect of the male elder from the male crosses with the females growing on the seed [3]. Furthermore, it is stated that the varieties of maize that exist in Indonesia have a hard seed properties as developed in the framework of protection against pest attack. This kind of variety has low protein content characteristics because it does not have an opaque-2 gene that controls protein levels. According to [12] the presence of opaque- 2 gene, can increase protein content, but on the other hand causes corn kernels are soft, and fragile. Breeding experts start developing corn plants that have high levels of protein by inducing opaque-2 genes into a variety, but they lead to undesirable traits such as low production and the fragility of seeds.

The result of the research shows that crossbreeding Local Waxy Corn with Srikandi Putih Variety produces seeds of F1 generation different from both parent, changes in shape and seed size (show Figure 1). Xenia can be seen from the character of its kernel color visually. On qualitative traits, the xenia symptoms affect the color of the seed, the shape of the seed, the shape of the fruit, and the cooking time [13]. The crossover results with the JTK-3, JU, A-1 and Bonansa parent with the female elder genotype, xenia appear only in the kernel color and kernel characters. These results differ from those reported by [7] in thorny palm, where the xenia affects almost all the quantitative characters of the observed fruit.

Table.2: Average Parameter of Production and Quality

of Waxy Corn and Srikandi Putih and F1 genotype

\begin{tabular}{|c|c|c|c|c|c|c|c|c|c|c|c|c|c|c|c|}
\hline \multirow[t]{2}{*}{ No. } & \multicolumn{3}{|c|}{$\begin{array}{l}\text { Length of the eal } \\
\qquad(\mathrm{cm})\end{array}$} & \multicolumn{3}{|c|}{$\begin{array}{l}\text { Diameter ear } \\
\text { (cm) }\end{array}$} & \multicolumn{3}{|c|}{$\begin{array}{c}\text { Weight of } 100 \\
\text { seeds } \\
(\mathrm{g})\end{array}$} & \multicolumn{3}{|c|}{$\begin{array}{c}\text { Weight of seeds } \\
\text { per plant }(\mathrm{g})\end{array}$} & \multicolumn{3}{|c|}{$\begin{array}{c}\text { Protein } \\
\text { Content } \\
(\%)\end{array}$} \\
\hline & WC & SP & $\mathrm{Fl}$ & WC & SP & $\mathrm{Fl}$ & WC & SP & $\mathrm{Fl}$ & WC & SP & $\mathrm{Fl}$ & $\mathbb{W C}$ & SP & $\mathrm{Fl}$ \\
\hline 1 & 12.4 & 15.4 & 14.2 & 3.4 & 4.7 & 3.7 & 30.7 & 35.2 & 31.2 & 18.2 & 80.2 & 26.5 & 8.4 & 10.4 & 9.2 \\
\hline 2 & 13.2 & 16.8 & 13.6 & 3.2 & 4.6 & 3.5 & 32.1 & 35.4 & 32.3 & 17.4 & 82.1 & 28.4 & 8.8 & 10.2 & 9.4 \\
\hline 3 & 12.8 & 17.9 & 14.4 & 3.4 & 4.5 & 3.7 & 30.5 & 36.2 & 32.8 & 17.6 & 81.5 & 25.8 & 9.1 & 10.5 & $\begin{array}{l}9.2 \\
\end{array}$ \\
\hline 4 & 13.5 & 16.6 & 13.8 & 3.5 & 4.4 & 3.6 & 31.5 & 35.8 & 33.2 & 16.8 & 78.8 & 24.6 & 8.2 & 10.8 & 9.4 \\
\hline 5 & 12.6 & 17.2 & 15.0 & 3.5 & 4.7 & 3.6 & 30.3 & 36.5 & 31.6 & 18.5 & 79.6 & 26.7 & 8.3 & 10.1 & 9.1 \\
\hline rage & 12.9 & 16.8 & 14.2 & 3.4 & 4.6 & 3.6 & 31.0 & 35.8 & 32.2 & 17.7 & 80.4 & 26.8 & 8.6 & 10.4 & 9,3 \\
\hline
\end{tabular}

Note: Wc=Waxy corn, SP=Srikandi Putih, F1=Genotype

F1 (hybridization Wc x SP)

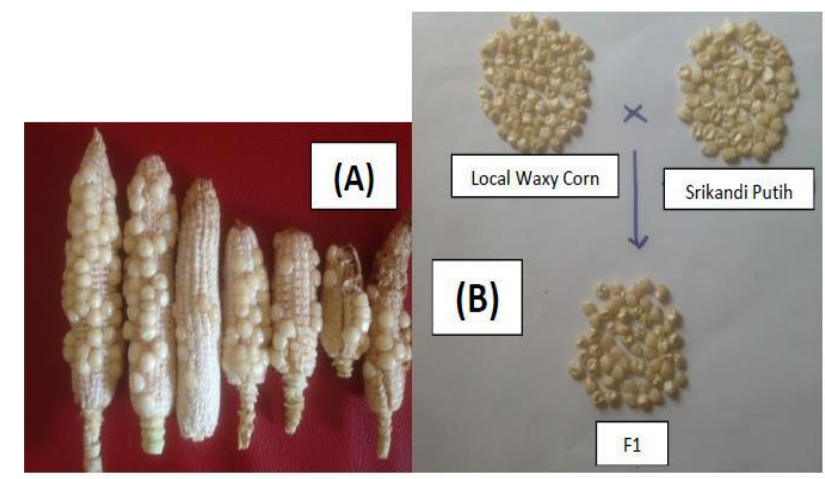

Figure 1. F1 Seed from the Local Waxy Corn Crossing with Srikandi Putih Variety (A): Cob F1; (B): Local Waxy Corn Seeds, Srikandi Putih Variety seeds, and F1 seeds

\section{CONCLUSIONS}

Based on the results of observations that have been done then it can be concluded as follows:

1. Character of plant height, number of leaves, and leaf area are higher in Srikandi Putih Variety compared to Local Waxy Corn

2. Age Flowering male and female Local Waxy Corn faster than Srikandi Putih Variety

3. Character length of ear, diameter of ear, weight of 100 seeds, plant seed weight and protein content higher in Srikandi Putih compared to Local Waxy Corn

4. In general, the value of F1 generation on each character of production and quality is between the value of both parents (Srikandi Putih Variety $\mathrm{x}$ Local Waxy Corn)

5. F1 protein content has increased $8.1 \%$ compared to Local Waxy Corn

\section{NOMENCLATURE}

F1 Filial 1 (Generation 1)

ô Male

우 Female

\section{ACKNOWLEDGEMENTS}

This research is supported financially by Directorate of Research and Community Service (DRCS) Research Department, Technology, and Higher Education (RistekDikti) Republic of Indonesia in the form of Research Scheme of Superior University. Therefore, we would like to thank the director and staff of DRPM Ristek-Dikti, Head of Research and Development Institute of LP2S and Dean of the Faculty of Agriculture of Muslim University of Indonesia (UMI) and the students for their assistance so that this Phase I research could Finished successfully. 


\section{REFERENCES}

[1] Alexander DE, Creech C. 1977. Breeding special nutritional and industrial types. In: Corn and Corn Improvement. The American Society of Agronomy Inc.

[2] Azrai, M., MJ. Mejaya, and M. Yasin H.G, 2008. Special Maize Breeding, Cereal Crops Research Institute, Maros (Translation: Azrai, M., MJ. Mejaya, dan M. Yasin H.G, 2008. Pemuliaan Jagung Khusus, Balai Penelitian Tanaman Serealia, Maros).

[3] Bullant, C. and Gallais. 1998. Xenia Effects In Maize Whit Normal Endosperm: I Importance and Stability. Crop Sci 39: 1517-1525. (On line). (Http: // www.google.com/search?hl=en\&q= Xenia + Effect \& meta $=$ ) Retrieved 12 August 2006.

[4] Iriani Neni, Andi Takdir M., Nuning, AS., Musdalifah Isnaini, and Marsum Dahlan. 2006. Improvement of Potential of Waxy Corn Yielt. Seminar and Workshop of National Maize 2005. Makassar 29-30 September 2005. P41-45. (Translation: Iriani Neni, Andi Takdir M., Nuning, AS., Musdalifah Isnaini, dan Marsum Dahlan. 2006. Perbaikan Potensi Hasil Populasi Jagung Pulut. Seminar dan Lokakarya Nasional Jagung 2005. Makassar 29-30 September 2005. P41-45.

[5] Jugenheimer, R.W. 1985. Corn Improvement, Seed Production, and Uses. Robert E. Krieger Publishing Company Malabar, Florida

[6] Mertz ET., L.S. Bates, and O.E. Nelson, 1964. Mutant gene that changes protein composition and increases lysine content of maize endosperm. Science 145, P: 279-280.

[7] Nandariyah, Edi Purwanto, Sukaya, and Sasono Kurniadi. 2000. Influence of male parent in crosses to the production and chemical content of thorny palm pondoh super. Zuriate Journal 11: 33-38.( Translation: Nandariyah, Edi Purwanto, Sukaya, dan Sasono Kurniadi. 2000. Pengaruh tetua jantan dalam persilangan terhadap produksi dan kandungan kimiawi buah salak pondoh super. Jurnal Zuriat 11: 33-38.

[8] Nelson, O.E., E.T. Mertz, and L.S. Bates. 1965. Second mutant gene affecting the amino acid pattern of maize endosperm proteins. Science. 150, P: 1469-1470.

[9] Pabendon, M. 2013. Realizing National Waxy Corn Variety. ANTARA NEWS. Retrieved 5 April 2017.( Pabendon, M. 2013. Mewujudkan Varietas Jagung Pulut Nasional. ANTARA NEWS. Diakses 5 April 2017).
[10] Pesireron, M., M.P. Sirappa and L. Dahamaruddin. 2013. Genetic diversity of local maize in Southwest Maluku District, Maluku Province. Proceedings of the National Seminar on Cereals. Increasing the Role of Cereals Research Towards Bioindustry Agriculture. Agency for Agricultural Research and Development. Puslitbangtan. Balitsereal. Maros. P.85. (Translation: Pesireron, M., M.P. Sirappa, dan L. Dahamaruddin. 2013. Keragaman genetik jagung lokal di Kabupaten Maluku Barat Daya, Provinsi Maluku. Prosiding Seminar Nasional Serealia. Meningkatkan Peran Penelitian Serealia Menuju Pertanian Bioindustri. Badan Penelitian dan Pengembangan Pertanian. Puslitbangtan. Balitsereal. Maros. p.85).

[11] Rifianto, A., 2010. Knowing Cor Pulut - Corn Sticky - (Waxy Corn), Zea mays ceritina Kulesh Onlinen:

http://azisrifianto.blogspot.co.id/2010/08/menge nal-jagung-pulut-jagung-ketan-waxy.html.

Accessed: April 5, 2017 (Translation: Rifianto, A., 2010. Mengenal Jagung Pulut - Jagung Ketan - (Waxy Corn), Zea mays ceritina Kulesh Onlinen:

http://azisrifianto.blogspot.co.id/2010/08/menge nal-jagung-pulut-jagung-ketan-waxy.html.

Diakses: 5 April 2017).

[12] Weingartner, U. 2002. Combining Cytoplasmic Male Strength And Xenia Increases Grain Yeild of Maize Hybrids. A Dissertation Submitted Swiss Federal Institute of Technology Zurich. Zurich. (Unpublished)

[13] Wijaya, Andi. 2007. Xenia Effect On Crosses of Corn Surya Variety With Srikandi Putih Variety on Corn seed Character. Journal of Agrosia Deed 2 (21): 199 - 203. (Translation: Wijaya, Andi. 2007. Efek Xenia Pada Persilangan Jagung Surya Dengan Jagung Srikandi Putih Terhadap Karakter Biji Jagung. Jurnal Akta Agrosia 2 (21): 199 - 203).

[14] Wikipedia. 2013. Waxy Corn, the Free Encyclopedia. Retrieved 5 April 2017.

[15]Zuber, M.S., W.H. Skrdla, and B.H. Choe. 1975. Survey of maize selections for endosperm lysine content. Crop Sci. 15, P: 93-94. 